\title{
Obstacles encountered by four major European astronomical observatories belonging to academies in the eighteenth century
}

\author{
E. CHASSEFIÈRE
}

SYRTE, Observatoire de Paris-Université PSL, CNRS, Sorbonne Université, 61 avenue de l'Observatoire, 75014 Paris, France. Tel. : 01405122 03, e-mail : eric.chassefiere@ obspm.fr.

\begin{abstract}
It is known that, in the first half of the 18th century, the conditions for astronomy at the Imperial Observatory of St-Petersburg, directed by Joseph-Nicolas Delisle, were comparable to those enjoyed by astronomers at the royal observatories of Paris and Greenwich created in the previous century ${ }^{1,2}$. But what about the public observatories created in the first half of the 18th century in Berlin, Uppsala and Bologna? The rich correspondence maintained by Joseph-Nicolas Delisle with the astronomers working in these observatories provides elements of an answer to this question. It also provides more precise information on Delisle's working conditions at the St-Petersburg Observatory. In this article, we present a comparative analysis of the obstacles encountered by astronomers at these different observatories, and the particular contexts in which they operated, including a breakdown by observatory of salaries and expenditure on astronomy equipment.
\end{abstract}

Key words: $18^{\text {th }}$ century, Scientific Academies, Berlin Observatory, Uppsala Observatory, Bologna Observatory, St-Petersburg Observatory, Joseph-Nicolas Delisle, resources for astronomy.

\section{Introduction}

In the second half of the 17th century astronomy continued to develop and to strengthen its institutional base, notably through the creation of two large observatories, the Paris

\footnotetext{
${ }^{1}$ René Sigrist, Alexander Moutchnik, "Entre Ciel et Terre:: les fonctions de l'astronomie sans la Russie du $18^{\text {ème }}$ siècle”, Almagest, International Journal for the History of Scientific Ideas, 6/2 (2015), 85-124, p. 98.

${ }^{2}$ Nina I. Nevskaja, “Joseph-Nicolas Delisle (1688-1768)", Revue d'histoire des sciences, 26, 4 (1973), 289-313, p. 292.
} 
Observatory created in 1667 as part of the new Royal Academy of Sciences ${ }^{3}$ founded the previous year, and the Greenwich Observatory created in 1675 as part of the Royal Society of London ${ }^{4}$ founded in 1660. In the following century many other academies were founded, including the Royal Academy of Prussia in Berlin in 1700, the Royal Society of Uppsala in 1710, the Academy of the Bologna Institute in 1714, the Imperial Academy of Arts and Sciences in St-Petersburg in 1725, and about fifteen others over the course of the 18th century ${ }^{5}$. The academies of Paris, London, Berlin, Uppsala, Bologna and St-Petersburg, which all had their own astronomical observatories, brought together between 30 and $40 \%$ of the European astronomers of the time. These astronomers did not confine their observation work to the observatories attached to these academies, far from it. In Paris alone, in the first half of the $18^{\text {th }}$ century, a dozen or so private observatories existed simultaneously and were used by the astronomers of the Royal Academy of Science ${ }^{6}$. In Europe as a whole, more than sixty mobile quarter circles were delivered to about fifty different observatories ${ }^{7}$ in the 17 th and 18th centuries, a fact that demonstrates the existence of numerous valuable observatories at that time.

The correspondence established by Joseph-Nicolas Delisle with a large number of European interlocutors $^{8}$ provides information on the concerns of astronomers at the time. The information exchanged mainly concerns eclipses and, more generally, the alignment events of the bodies in the solar system: eclipses of the moon and sun, occultations of planets (and fixed stars) by the moon, occultations of Jupiter's satellites by the planet, transits of Venus or Mercury over the sun, all events of considerable importance at the time, both for sizing the

\footnotetext{
${ }^{3}$ Alfred Maury, L'ancienne Académie des Sciences (Paris, 1864).

4 Édouard Mailly, Essai sur les Institutions Scientifiques de la Grande-Bretagne et de 1'Irlande (Bruxelles, 1867).

5 René Sigrist, "Les communautés savantes européennes à la fin du siècle des Lumières", M@ppemonde 110 (2013.2), http://mappemonde-archive.mgm.fr/num38/articles/art13204.html, p. 3.

${ }^{6}$ Irène Passeron, "L'Académie des sciences et l'Observatoire de Paris sont-ils parisiens ?", T. Belleguic et L. Turcot. Histoire de Paris. De l'âge classique à la modernité (XVIIe-XVIIIe siècles) Tome I (Hermann, 2013), 185-198, p. 189.

${ }^{7}$ A. J. Turner, "The Observatory and the Quadrant in Eighteenth-Century Europe", Journal for the History of Astronomy, xxxiii (2002), 373-385, p. 378-379.

${ }^{8}$ Correspondance de Joseph-Nicolas Delisle:: Inventaire détaillé, 1709-1767, B1/1-8, E1/13, B2/5, Bibliothèque numérique de l'Observatoire de Paris, https://bibnum.obspm.fr/.
} 
solar system and for measuring the latitudes and longitudes of places for cartographic purposes. In addition, Newtonian scientists such as Delisle set themselves the goal of validating Newton's law of gravitational attraction through precise measurements of the planets' trajectories. With regard to the States or Cities that financed them, the missions of the observatories mainly concerned cartography and navigation, and not astronomical observation for its own sake, generating tensions between politicians and scientists, which, as we shall see, could be heated at times.

But, what were working conditions like in the State Observatories founded within the Academies? Delisle's correspondence provides elements of an answer to this question. In this article we consider letters exchanged with Christine Kirch and Johann Wilhelm Wagner at the Berlin Observatory, Eustachio Zanotti at the Bologna Observatory, various European interlocutors concerning the St-Petersburg Observatory (which Delisle himself headed), and Anders Celsius and Pehr Wilhelm Wargentin at the Uppsala Observatory. In part 2, for each of the four academies, after having briefly described the context of the creation of the observatories attached to them, we analyse the elements of Delisle's correspondence which provide information on the working conditions in these observatories, and the obstacles encountered by the astronomers in carrying out astronomical research. In part 3, we summarise the various types of obstacles encountered and specify for each of them the exact nature of the difficulties and how they fit within the context of the academies concerned. In particular, we present a comparative study of astronomers' salaries and equipment budgets in the four observatories studied, as well as in the two observatories created in the previous century in Paris and Greenwich.

\section{Analysis of the correspondence of Joseph-Nicolas Delisle}

\subsection{Correspondence with Christine Kirch and Johann Wilhelm Wagner at the Berlin} Observatory (1741-1745)

\subsubsection{Context}

On 11 July 1700 in Cologne, Friedrich III of Brandenburg, who would become King Friedrich I of Prussia the following January, signed the letters patent establishing the new Society of 
Sciences in Berlin ${ }^{9}$. The following day, Gottfried Wilhelm Leibniz was appointed Life President of the Society. The rules of the Berlin Society put much emphasis on the applied nature of science and its usefulness to society. Leibniz did not establish a philosophy class because he wanted to banish pure speculation from the programme. The development of astronomy offered an opportunity for self-financing through the sale of calendars. The Improved Calendar, introduced 1 March 1700, required an astronomical calculation of Easter instead of the cyclic Easter tables of the Julian and Gregorian calendars ${ }^{10}$, thus the help of astronomers was indispensable. In a letter, dated 5 March 1700, Leibniz asks the Danish astronomer Ole Christensen Roemer for advice in the context of a decision by a Prince to build an observatory where one or two astronomers might study the $\mathrm{sky}^{11}$. In particular he asks for advice on the building and on which instruments would be most useful. Leibniz repeats the question on $18 \mathrm{March}$, in a letter in which he also argues against a monopoly for almanacs because of the loss of competition. He expresses his preference for a tax instead. As early as 1700 , he attracted the astronomer Gottfried Kirch to Berlin by appointing him "First Astronomer of the Royal Society of Sciences". Kirch was in particular tasked with drawing up calendars and real ephemerides in order to raise the necessary funds for the construction of the Observatory, where the meetings of the members of the Society were to be held. He was helped in this work by his wife Maria Winkelmann, also an astronomer, who devoted a large part of her time to the creation of these calendars and ephemerides until her death in 1720 .

The building of the Observatory was almost complete by 1710, and the King ordered that the Society be installed there. That year, following the death of Gottfried Kirch, the German astronomer Henri Hoffmann took over the management of the fledgling Observatory. After his death in 1716, he was replaced by Christfried Kirch, son of Gottfried Kirch and Maria Winkelmann. The inauguration ceremony was set for 19 January 1711 , but not only did Friedrich not consult Leibniz on the definitive establishment of the Academy, he also failed to invite him to the inauguration. Leibniz was supplanted as president of the society by Baron van Printzen, Minister of the Interior, and only retained the honorary title, an act that marked the State's desire to take direct control of the Academy. It was foreseen that upon Leibniz's

\footnotetext{
${ }^{9}$ Christian Bartholmess, Histoire Philosophique de l'Académie de Prusse, Tome Premier (Paris, 1850).

${ }^{10}$ See e.g. https://webspace.science.uu.nl/ gent0113/easter/easter_text3b.htm

${ }^{11}$ Personal communication from a Referee of the paper.
} 
death Printzen alone would govern the society as honorary president. Officially, Printzen and Leibniz co-chaired the society until Leibniz' death in $1716^{12}$, and Printzen was president from 1716 to 1718. The members of the Academy were not remunerated, but the costs of equipment and infrastructure were borne by the King, as outlined by the Vice-President of the Academy Daniel Ernest Jablonski at the opening ceremony: "We are not charged with any expenses; we have, thanks to the Royal Protection, all that is necessary to excite our activity, $\&$ to encourage our work, to acquire mathematical instruments, books, \& to provide us in general with other necessary things" 13 .

The death of Friedrich I in 1713, and his succession by Friedrich Wilhelm I, whose reign was to last twenty-seven years, marked the beginning of a long barren spell for the Academy, with the new king scorning the arts and sciences. In fact the Academy came very close to dissolution. In 1731, Jablonski was appointed president of the Academy. The political leadership was handed over to Adam Otto von Viereck, a minister who became "Protector" of the Academy, a position that Friedrich I had assumed, but not his successor. In 1735, Jablonski and Viereck succeeded in convincing the king to detach all works relating to mathematics and the physical sciences from the royal library to the Academy's hitherto poorly stocked library. They also revived the publication of the memoirs, the first volume of which had appeared in 1710 under the aegis of Leibniz. The death of Friedrich Wilhelm in 1740, and the advent of Friedrich II, known as "Frederick the Great", marked the real resurrection of the Academy. The Silesian Wars between 1740 and 1763 delayed its revival, but at the same time brought new income to the Academy with the extension of the privilege to produce calendars for the kingdom's newly acquired territory; Christine Kirch, sister of Christfried Kirch, was henceforth responsible for producing calendars for Silesia. Christfried Kirch died in 1740 and was replaced as Director of the Observatory by Johann Wilhelm Wagner.

The Academy was re-founded in 1746 under the aegis of Marshal Samuel Graf von Schmettau. He was instrumental in extending the Academy's membership to include amateurs of science and literature from within the Court and the State apparatus. The new society was similar to the one founded by Leibniz in that it focused on the experimental and practical side

\footnotetext{
${ }^{12}$ See https://praesidenten.bbaw.de/de/002.

${ }^{13}$ Histoire de l'Académie Royale des Sciences et des Belles Lettres, depuis son origine jusqu'à présent (Berlin, 1752), p. 45.
} 
of science. But it differed from Leibniz' vision in two respects: the introduction of the study of speculative philosophy and the use of the French language, which lent the enterprise a more literary and modern European flavour. After a few years, Friedrich ordered the organic reunion of the two societies as "a perfected continuation of the Society founded by Leibniz". By merging the two societies, Schmettau and a commission set up for the occasion created the "Royal Prussian Academy of Sciences and Fine Letters". Two years later, on 3 March 1746, Pierre Louis Moreau de Maupertuis, who had come to settle in Prussia, became the "Perpetual President" of the Academy, and Friedrich II officially took the title of "Protector". In 1764, Jean Bernoulli took over the direction of the Observatory and the first quality instrument, a large wall quarter-circle, was ordered in October 1768 from the English manufacturer John Bird $^{14}$.

\subsubsection{The obstacles encountered by Johann Wilhelm Wagner}

In a letter of April $1741^{15}$, Christine Kirch confided to Delisle that she had not had time to catalogue her brother's observations accurately because she had "had a lot of work to do with foreign calendars". In a letter of July $1744^{16}$, she explained to Delisle that Wagner did not help her much with the cataloguing work, because "the calendars, his age and all sorts of fatalities sometimes put him in a bad mood". In several letters written to Delisle between 1741 and 1744, Wagner mentions the making of calendars as the main obstacle to his work as an astronomer, as he was "almost all year long overburdened with the work of the almanacs (of several species) which provide the background for the maintenance of the Science Society" $^{17}$.

\footnotetext{
${ }^{14}$ Julius Dick, "The 250th Anniversary of the Berlin Observatory" (Reprinted from Die Sterne, Vol. 26, Nos. 11-12, 1950, 161-171), Popular Astronomy 59 (1951), 524-535, p. 527.

${ }^{15}$ Kirch, Christine (1696-1782), "Lettre de Christine Kirch à Joseph-Nicolas Delisle, Berlin, 25 avril 1741," Bibliothèque numérique - Observatoire de Paris, consulted 11 February 2021, https://bibnum.obspm.fr/ark:/11287/bVh4M.

${ }^{16}$ Kirch, Christine (1696-1782), "Lettre de Christine Kirch à Joseph-Nicolas Delisle, Berlin, 24 juillet 1744," Bibliothèque numérique - Observatoire de Paris, consulted 11 February 2021, https://bibnum.obspm.fr/ark:/11287/1P041

${ }^{17}$ Wagner, Johann Wilhelm (1681-1745), "Lettre de Johann Wilhelm Wagner à Joseph-Nicolas Delisle, Berlin, 24 juillet 1742,” Bibliothèque numérique - Observatoire de Paris, consulted 11 February 2021, https://bibnum.obspm.fr/ark:/11287/2vcrw.
} 
In a letter to Delisle in September $1744^{18}$, Wagner told him that the state in which he had once seen the Observatory, when he visited it at the end of 1725 on the way to St-Petersburg, had improved little, and he added: "there are many instances where the instruments, which first strike the eye, are not fit to do anything right". In reality, the Academy ran in slow motion throughout the reign of Friedrich Wilhelm I. Wagner provides Delisle with the following description of the Observatory in his letter of July $1742^{19}$ :

You have, Sir, seen the Observatory (16 years ago) and know that it deserves to be better established and equipped with better instruments; there are some, especially quarter circles, large and small, but none of them are accurate or suitable enough to provide accurate observations; the Observatory building itself does not have the capacity required to place the instruments in an appropriate way, as I realised to my great dissatisfaction recently, during the appearance of the Comet; also lacking are some exquisite telescopes (with micrometers) of a suitable and handy size; we have three of them, a little large and quite good, 18, 20 and 25 feet long, one of which is made by Campani in Rome, but there is no place to use them with ease.

In the same letter, he gives two reasons which prevented "a better establishment": firstly that "the funds of the Society are not sufficient", and secondly that "since two years ago, when the rumour started to spread again that His Majesty our King had the great intention of building a pleasure castle with a large garden in place of the stables and the Observatory". Hence any

\footnotetext{
${ }^{18}$ Wagner, Johann Wilhelm (1681-1745), "Lettre de Johann Wilhelm Wagner à Joseph-Nicolas Delisle, Berlin, 5 septembre 1744," Bibliothèque numérique - Observatoire de Paris, consulted 11 February 2021, https://bibnum.obspm.fr/ark:/11287/2DWQM.

${ }^{19}$ Wagner, op. cit. (ref. 17). Original excerpt: "Vous aves, Monsieur, vû l'observatoire (il y a 16 ans) et le connoissez, qu'il merite d'étre mieux établi et instruit de meilleurs instrumens; il y en a bien, particulierement des quarts de cercle, grands et petits, mais dont aucun n'est assez just ou propre à étre employé à en faire des exactes observations; l'edifice de l'observatoire même n'a pas la commodité duë à placer çà et là les instrumens, comme je l'ay trouvé dernierement à mon grand mécontentement, pendant l'apparition de la Comete; il y manque aussi quelques exquises lunettes d'approche (avec des micrometres) d'une grandeur convenable et maniable; nous en avons bien trois, un peu grandes et assez bonnes, longues de 18. 20 et 25. pieds, dont l'une est fait de Campani à Rome, mais le lieu manque, où l'appareil aussi n'est depuis plusieurs années en état d'en les pouvoir elever pour s'en servir à son aise".
} 
project to renovate the Observatory, which was in danger of being demolished, had been frozen. The project threatening the Observatory was probably part of the great architectural projects of Friedrich II who, after the death of Friedrich Wilhelm in May 1740, decided to have a new building constructed for the Academy, as well as various palaces and prestigious buildings ${ }^{20}$. In his letter of February 1744 to Delisle ${ }^{21}$, Euler said he was mistaken in thinking that "the new Academy would be put on the same footing as the one in Paris", because its members received "no pension, or very little" because the Academy's only income was "from the almanacs", which did not bring in "very much". However, he adds:

Every effort is being made to increase the funds, and it has already been proposed to put the Observatory back on a good footing; but as excellent instruments would have to be brought in from England for this purpose, and good astronomers could not be found for so little pay, I don't know yet how much I can hope for in this undertaking.

Thus, it was not only the lack of funds of the Academy that was detrimental to astronomy, by preventing the purchase of good instruments, but also the insufficient salary of the astronomers, which prevented the observatory from attracting the best scholars. In passing, he said he regretted that Delisle could not come and take over the management of the Berlin Observatory. Wagner wrote to Delisle in September $1744^{22}$ that "the Academy of Sciences has bought from the heirs of the late Mr von Krosigk, the instruments, namely a quarter circle azimuthal, with a horizontal ring and a sextant, which I used in the past at Mr von Krosigk's observatory, which will soon be [in] place at the platform of the Royal Observatory". Baron von Krosigk, an amateur astronomer, had a private observatory installed in 1705. Gottfried Kirch, Christfried's father, had made observations there until his death in 1710, as the construction of the Academy's Observatory was not yet complete at that time ${ }^{23}$. His widow, Maria Winkelmann, was invited by Krosigk to move into a dwelling adjoining his observatory, where she observed until Krosigk's death in 1714. It is known that in 1733 Krosigk's eldest son sent Wagner "a number of papers concerning astronomy", a selection of

\footnotetext{
${ }^{20}$ Bartholmess, op. cit. (ref. 9), p. 206.

${ }^{21}$ Euler, Leonhard (1707-1783), "Lettre de Leonhard Euler à Joseph-Nicolas Delisle, Berlin, 1 février 1744," Bibliothèque numérique - Observatoire de Paris, consulted 11 February 2021, https://bibnum.obspm.fr/ark:/11287/1hZ8s.

${ }^{22}$ Wagner, op. cit. (ref. 18).

${ }^{23}$ Histoire, op. cit. (ref. 13), p. 62.
} 
which Wagner sent to Delisle ${ }^{24}$. This purchase of equipment that was already some forty years old shows how critical the Observatory's financial situation was at that time.

\subsection{Correspondence with Eustachio Zanotti at the Bologna Observatory (1749)}

\subsubsection{Context}

It was from the Accademia degli Inquieti, an informal circle founded in 1690 in Bologna by Eustachio Manfredi, then a young astronomy enthusiast, that the Academy of Bologna was established at the beginning of the 18 th century ${ }^{25}$. Giovanni Domenico Cassini had been a professor of mathematics and astronomy at the University of Bologna for nearly twenty years (before being lured to Paris to preside over the new Paris Observatory), making Bologna a legitimate location for an observatory. The Academy was born from the rapprochement that took place from 1700 between Manfredi and Count Luigi Ferdinando Marsigli, a military expert in hydraulics who, in the course of his travels, collected books, scientific instruments, minerals and natural fossils. On his return to Bologna in 1702, after having served in the Austrian army, Marsigli put his collections, books and instruments at the disposal of the Inquieti. In 1703 he had an observatory built on his palace, which Manfredi and his friends began to use for their observations. In 1705 the meeting place of the Inquieti was moved to the Marsigli Palace. In 1709, Marsigli applied to the Bologna Senate for the establishment of an Institute, to which he promised to donate his collections. The Senate of Bologna agreed in principle, but lacked the necessary resources to carry out the project and asked Marsigli to apply to the Vatican for help. With the Pope's approval, the Senate of Bologna officially received Marsigli's donation in January 1712. Palazzo Poggi, where Marsigli's collections were to be housed, was prepared for the Accademia degli Inquieti, renamed for the occasion the "Academy of Sciences of the Institute of Bologna". The newly created Institute and the Academy inherited from the former Accademia degli Inquieti nevertheless remained two administratively distinct entities. The Institute provided a tool for the Academy's scholarly

\footnotetext{
${ }^{24}$ Samuel Formey, "Éloge de Monsieur le Baron de Krosick", Nouvelle Bibliothèque Germanique, ou Histoire Littéraire de l'Allemagne, de la Suisse, \& des Pays du Nord, Juillet, Août et Septembre 1756, Tome dix-neuvième, Première partie (1756), 17-36, p. 24.

${ }^{25}$ Luciano Boschiero, "The Young and the Restless:: Scientific Institutions in late $17^{\text {th }}$-century and early $18^{\text {th }}$-century Italy". Working Papers, Columbia University, 2004, https://academiccommons.columbia.edu/doi/10.7916/D8V98FDP, p. 13-16.
} 
members to conduct their research in a coordinated manner. As Fontenelle notes ${ }^{26}$, the fact that these institutions remained administratively distinct suggests that Marsigli encountered political difficulties in achieving his goal. The university professors appointed to the Institute were all academics, and it was from among these professors that the first heads of the Academy were chosen: a president, a vice-president and a secretary ${ }^{27}$. There were six subjects at the Academy: physics, mathematics, medicine, anatomy, chemistry and natural history. The Institute was placed under the direction of an office, composed of ten senators ${ }^{28}$, which rendered it directly dependent on the political power.

The new Academy was solemnly inaugurated on 13 March 1714 in the presence of the political and religious authorities. In spite of its promising beginnings, the Institute quickly began to lose momentum, failing to fulfil the hopes that Marsigli had placed in it to become a research centre at the highest European level, on a par with the Paris and London academies. On his return to Bologna in 1723, he found that the Institute was merely a place of intellectual entertainment. He then came into conflict with the Bologna senate, which headed the Institute, and which he blamed for the lack of interest in the scientific project. Among the remedies he proposed were, in particular, the opening up the professorships at the University of Bologna to non-Bolognese and the raising of the salaries of the professors. Marsigli's book of grievances ends with a request to the Pope, should the Bologna Senate refuse his recommendations. The Pope's reply was favourable and on 24th March 1727 Marsigli supplemented his donation of 1712. In the meantime, improvements were made, including the construction of the Astronomical Observatory Tower, started in 1712 and completed in 1725, while the Specola over the tower was completed in December $1726^{29}$. Nevertheless, the situation did not improve. Dissatisfied with the behaviour of politicians and some university professors, Marsigli announced in a letter of 10 July 1728 to the Pope that he was leaving the city and disengaging from the Institute. But in his fight for the success of the Institute,

${ }^{26}$ Bernard le Boyer de Fontenelle, "Éloge de M. le Comte Marsigli", Éloges des académiciens de l'Académie Royale des Sciences, morts depuis l'an 1699, Nouvelle édition, Tome second (Paris, 1766), 399-417, p. 413.

${ }^{27}$ Henri Philippe de Limiers, Histoire de l'Académie Appelée l'Institut des Sciences et des Arts, Établi à Boulogne en 1712 (Amsterdam, 1723).

${ }^{28}$ Joseph Jérôme Lefrançois de Lalande, Voyage en Italie, Tome Second (Genève, 1790), p. 63.

${ }^{29}$ A history of astronomy in Bologna can be found in Enrica Baiada et al., "Museo della Specola", Part 1, Astronomy in Bologna, Bologna 1985, pp. $54-56$ (online at: https://museospecola.difa.unibo.it/) 
Marsigli was supported by an eminent representative of the church, Prospero Lorenzo Lambertini, a native of Bologna, archbishop of that city from 1730 and elected Pope under the name of Benedict XIV in 1740, and it was through him that Marsigli obtained the Pope's support in 1727. Upon his accession to the papacy Lambertini hastened to consolidate Marsigli's work with a series of major actions designed to strengthen the Institute ${ }^{30}$, including, in 1741, the purchase of astronomical instruments for the Academy Observatory from the makers George Graham and Jonathan Sisson in London.

\subsubsection{Obstacles encountered by Eustachio Manfredi and Eustachio Zanotti}

In a letter sent to Delisle in January $1749^{31}$, Eustachio Zanotti, Director of the Bologna Observatory, told his correspondent that he did not plan to publish all of the observations made in Bologna since the creation of the Observatory, as the measurements made before 1742, the year the instruments purchased in London were installed, were too inaccurate. In the same letter, Zanotti informed Delisle that Mandrefi "was often diverted by many other occupations. And mainly by the river business, which gave Bologna people a lot to think about." In 1704 Manfredi was appointed Superintendent of Water, a position he held until his death, to the benefit, Fontenelle writes, of hydrostatics, but to the detriment of astronomy ${ }^{32}$. It is known that Manfredi, at the time of his appointment as Professor of Mathematics at the University of Bologna in 1699, faced great financial problems due to his low salary ${ }^{33}$, and his acceptance of the position in the field of water management was certainly motivated by the need to increase his income. Zanotti refers in his letter to observations made prior to 1742 with a telescope equipped with a micrometer, but indicates that he did not have a large

\footnotetext{
${ }^{30}$ Georgio Dragoni, "Marsigli, Benedict XIV and the Bolognese Institute of Science", Renaissance and Revolution: Humanists, Scholars, Craftsmen and Natural Philosophers in Early Modern Europe, Field, J.V. (Cambridge University Press, 1994), 229-238, p. 231-233.

${ }^{31}$ Zanotti, Eustachio (1709-1782), "Lettre de Eustachio Zanotti à Joseph-Nicolas Delisle, Bologne, 10 janvier 1749," Bibliothèque numérique - Observatoire de Paris, consulted 12 February 2021, https://bibnum.obspm.fr/ark:/11287/nMGw4.

${ }^{32}$ Bernard le Boyer de Fontenelle, "Éloge de M. Manfredi", Éloges des académiciens de l'Académie Royale des Sciences, Morts depuis l'an 1699, Nouvelle édition, Tome second (Paris, Libraires Associés, 1766), 535-559, p. 546.

33 Ugo Baldini, "Manfredi Eustachio", Dizionario Biografico degli Italiani, Volume 68 (2007), https://www.treccani.it/enciclopedia/eustachio-manfredi_\%28Dizionario-Biografico\%29/.
} 
number of these measurements, apparently due to the lack of input from Manfredi who was absorbed by his function as Water Superintendent.

It should be noted, however, that despite his other occupations, Manfredi did a remarkable job as an astronomer. His observations (published in 1731 under the title De novissimis circa fixorum siderum errores observationibus) were the first (and for years the only) study confirming Bradley's 1727/28 theory of the stellar aberration of light. Moreover, the term "aberration", still used today, derives from the title of Manfredi's 1729 book De annuis inerrantium stellarum aberrationibus ${ }^{34}$. Furthermore, he showed the variation of the inclination of the ecliptic having collected observations over a period of more than 70 years using both the Cassini and Montanari meridian lines in Bologna ${ }^{35}$. As regards Zanotti, the catalogue of more than 400 stars that he compiled (Ephemerides motuum coelestium ex anno 1751, in annum 1762, Bologna 1750) is considered the first (or at least one of the first) to be based on modern criteria, taking into account Bradley's aberration as well as other astronomical effects.

\subsection{Correspondence between Joseph-Nicolas Delisle at the St-Petersburg Observatory and various contacts in Europe (1729-1758)}

\subsubsection{Context}

At the beginning of the 18th century, in a period of rapid development of geometric methods for large-scale mapping using triangulation, supplemented by astronomical observations of latitude and longitude, several States, including Russia, committed considerable resources to mapping their territories. In 1698, Tsar Peter the Great, visiting the Royal Society and the Royal Observatory in Greenwich, hired the Scotsman Henry Farquharson to head the Moscow School of Mathematics and Navigation ${ }^{36}$. This School was officially established in 1701, and

\footnotetext{
${ }^{34}$ See Baiada et al. cited before (ref. 29) pp. 63 ff., and details in Gualandi et al., "The search for stellar parallax and the discovery of the aberration of light: the observational proofs of the Earth's revolution, Eustachio Manfredi and the 'Bologna case", Journal for the History of Astronomy, Vol. 40, Part 2, May 2009, No. 139, pp. 155-172.

${ }^{35}$ John L. Heilbron, The Sun in the Church (Harvard University Press, 1999).

36 John H. Appleby, "Mapping Russia: Farquharson, Delisle and the Royal Society", Notes and Records of the Royal Society of London, 55, 2 (2001), 191-204.
} 
Peter the Great endowed Farquharson with books and scientific instruments. In 1715, the School was renamed the Naval Academy, and was transferred to St-Petersburg, the new capital of the empire. Here it was to play the role of Russia's leading scientific centre, training generations of explorers, cartographers, mathematicians, surveyors, astronomers and engineers in all fields of interest for the modernisation of Russia. Between 1717 and 1719, all the collections of scholarly works in Peter the Great's summer palace were transferred to the Naval Academy, before joining the cabinet of curiosities of the future Academy of Sciences, which was founded in 1725. Numerous geodesists were trained at the Naval Academy in the 1710 s and 1720 s, and sent to carry out field surveys. Wishing to establish scientific relations between Russia and France, as he had done with England, Peter the Great went to France in 1717, with the aim of establishing links with the learned world ${ }^{37}$. He proposed to the geographer Guillaume Delisle that he come to St-Petersburg to work on the cartography of Russia, but the latter declined and put forward the name of his brother Joseph-Nicolas, a renowned astronomer and specialist in position measurements by astronomical methods. This choice, accepted by Peter the Great, provided the opportunity to set up an astronomical observatory in St-Petersburg as part of the new Imperial Academy of Sciences in the making.

In January 1724, Peter the Great presented a document describing the Academy project to the Russian Senate ${ }^{38}$. The Academy consisted of three classes, or departments. The first two departments were identical in their outline to the departments of "mathematics" and "physics and medicine" of the Berlin Academy when it was created in 1700, the third more or less overlapping with the departments of philology and national history of the Berlin Academy. The question of language was presented differently in St-Petersburg, however, since it was through the study of foreign languages that the Academy aimed to further the desired Europeanisation of Russia. As in Paris, the members of the Academy received a salary, and funds were allocated for infrastructure, equipment and technical staff. Unlike the main academies that were created at the same time, or that were formed in the second half of the 17 th century, the academic circle was not formed on the basis of pre-existing academies or

${ }^{37}$ Marie-Anne Chabin, "Moscovie ou Russie ? Regard de Joseph-Nicolas Delisle et des savants français sur les États de Pierre le Grand”, Dix-huitième Siècle, 28 (1996), L'Orient, p. 43-56.

${ }^{38}$ Maria Rosa Massa Esteve, “The circulation of scientific knowledge in Euler's first stage at Saint Petersburg Academy of Sciences", The scientific dialogue linking America, Asia and Europe between the $12^{\text {th }}$ and the $20^{\text {th }}$ Century. Theories and techniques travelling in space and time, by F. D'Angelo (Naples, Associazione culturale Viaggiatori, 2018), 262-276. 
communities of scholars. Leibniz's recommendation to bring in foreign scholars was followed to the letter, and it was mainly from Protestant Germany that the first class of scholars arrived. Among the subjects of interest to Peter the Great was the application of mathematics, astronomy and chemistry to the construction of ships, canals and ports, but also to the improvement of navigation, artillery, mining and public health. Given the virtual nonexistence, at the turn of the 18th century, of a national public education system in Russia, the project included, in accordance with Leibniz's wish, the creation of a university attached to the Academy.

Architecturally, the Academy consists of two buildings on Vasilievsky Island ${ }^{39}$. In the first one are the Observatory (the central tower), the natural history museum and the library. This building was started in 1718, under Peter the Great, well before the foundation of the Academy, and its construction was spread over ten years, under the successive responsibility of several architects. It was completed in 1727-1728, and Delisle had his observatory installed on three floors of the tower. The second building, adjacent to the first and built at the same time, included a meeting room for the academicians, the Academy administration and the academic office under the direction of Johann Daniel Schumacher, a geographical department that published maps of Russia, the offices of the translators involved in the Academy's publishing activities, a printing workshop and a bookshop. On his arrival, Delisle had at his disposal the instruments that he had brought with him from Paris, and a little later he was able to use a quarter-circle and an English-made sextant purchased by Peter the Great during his trip to London, and which were transferred for his use from the Naval Academy to the Observatory. He was assisted by two academicians, Wolfgang Ludwig Krafft and Friedrich Christoph Mayer (replaced by Christian Nicolas von Winsheim after Mayer's untimely death in 1729), with whom he carried out his programme of astronomical and meteorological observations, the volume of which has been judged "astonishing"40. Delisle did not immediately succeed in persuading the Russians to purchase a large quarter-circle that he himself had commissioned in Paris, but his wish was finally realised in 1735.

\footnotetext{
${ }^{39}$ K. I. Shafranovskij, "Les salles de l'Académie des sciences de St-Pétersbourg - en 1741”, Cahiers du monde russe et soviétique, 8, 4 (1967), 604-615.

${ }^{40}$ Othon Struve, "Sur les manuscrits de Joseph de l'Isle conservés à l'Observatoire de Paris", Recueil des Actes de la séance publique de l'Académie Impériale des Sciences de St-Pétersbourg tenue le 11 janvier 1847 (Leipzig, 1847), p. 91.
} 


\subsubsection{Obstacles encountered by Joseph-Nicolas Delisle}

In a letter to Count Jean-Frédéric Phélypeaux de Maurepas, Louis XV's Secretary of State for the Navy, dated 25 May $1729^{41}$, Delisle explained that the Observatory building was not completed, and would not be completed until the following year, four years after its installation in St-Petersburg at the beginning of 1726. Moreover, the Academy's finances had been used for something other than astronomy, since Vignon, the worker who accompanied Delisle to St Petersburg "was unable to execute here the astronomical instruments, the plans of which I had given him two years ago and of which he made the models, and this because the Academy has not so far been in a position to spend the money because of the considerable costs of its printing shop". On 3 January 1730, in a letter to Jean-Paul Bignon ${ }^{42}$, Delisle lamented how much his "work in geography [...], as in natural history and other fields of knowledge" diverted him from his "views in astronomy". Delisle indeed had to devote a large part of his time to the cartographic project, especially as he lacked the means to carry it out. It is known that from the outset the general secretary of the Senate, Kirilov, also a geographer, saw Delisle as a rival and succeeded "in depriving him of the collaboration of some geodesists whom he employed for his own work" ${ }^{43}$, publishing a map of Russia himself in 1734. Delisle was only assigned two geodesists for his project. He also lacked draughtsmen, as he complained in a letter addressed to Count Plélo ${ }^{44}$, the French ambassador to Denmark, in June 1732: "I would have been able, despite my other occupations, to complete the general map much better than all those which have appeared up to now, if I had been helped by a sufficient number of draughtsmen".

\footnotetext{
${ }^{41}$ M. H. Omont, "Lettres de J.-N. Delisle au Comte de Maurepas et à l'Abbé Bignon sur ses travaux géographiques en Russie (1726-1730)", Bulletin de la Section de Géographie, Tome XXXII (Paris, Imprimerie Nationale, 1917), 134-148, p. 147.

${ }^{42}$ Omont, op. cit. (ref. 41), 156-158, p. 156.

${ }^{43}$ Albert Isnard, "Joseph-Nicolas Delisle, sa biographie et sa collection de cartes géographiques à la Bibliothèque Nationale", Bulletin de la Section de Géographie, Tome XXX (Paris, Imprimerie Nationale, 1915), p. 44-45.

${ }^{44}$ Miguel Benitez, "Trois lettres de J.-N. Delisle au comte de Plélo. L'exploration de la Sibérie”, Dixhuitième Siècle, 18 (1986), Littératures françaises, 191-200, p. 192.
} 
Despite these difficulties, Delisle wrote a letter to Christfried Kirch, Director of the Berlin Observatory, in June $1735^{45}$ praising the Imperial Observatory, explicitly aimed at convincing Kirch to come and replace him at the head of the Observatory, as by then he wished to leave Russia. It is not certain that he was perfectly sincere in his praise of the existing resources, although at that time the Observatory's array of instruments had grown considerably compared to what it was in the early years. In 1738, a second quarter circle was in place, probably the one from France, as well as a number of new instruments ${ }^{46}$. Despite the recent acquisitions, in a letter written to Anders Celsius in December $1743^{47}$, he wrote a clearly negative assessment of the resources made available to him since his arrival in St-Petersburg: "for me, in spite of all the trouble I have taken since I have been in Russia, I have not been able to contribute to the advancement of astronomy as much as I would have liked. The little help I have received from those who have been in charge of the Academy so far has led to the failure of all my plans". The atmosphere at the Academy was at its lowest point in 1743 following a complaint filed against Schumacher by Andrey Nartov for mismanagement of finances and other malpractices ${ }^{48}$. As for Delisle, he was relieved of his duties as Director of the Geography Department of the Academy at the end of 1740, and consequently of responsibility for the cartography project of Russia, partly because of the slow progress of the map of Russia for which he was responsible, but also because of suspicions of espionage that had been hanging over him since 1738. In fact, he was suspected of having transmitted maps of Russia to the French government. His salary was suspended at the end of 1740, as he wrote

${ }^{45}$ Delisle, Joseph-Nicolas (1688-1768), "Lettre de Joseph-Nicolas Delisle à Christfried Kirch, StPétersbourg, 16 juin 1735," Bibliothèque numérique - Observatoire de Paris, consulted 12 February 2021, https://bibnum.obspm.fr/ark:/11287/XNMSr.

${ }^{46}$ Othon Struve, "Esquisse historique de l'Observatoire de l'Académie des Sciences de St-Pétersbourg et des travaux astronomiques exécutés en Russie pour l'avancement de la Géographie du pays", Description de l'Observatoire Astronomique Central de Poulkova (St-Pétersbourg, 1845), p. 6-8.

${ }^{47}$ Delisle, Joseph-Nicolas (1688-1768), "Lettre de Joseph-Nicolas Delisle à Anders Celsius, StPétersbourg, 27 décembre 1743," Bibliothèque numérique - Observatoire de Paris, consulted 12 February 2021, https://bibnum.obspm.fr/ark:/11287/1zS91.

${ }^{48}$ Valerie Leonov, "Libraries in Russia, History of the Library of the Academy of Sciences from Peter the Great to Present" (K. G. Saur, 2005), p. 74-87. 
to Euler in September $1743^{49}$. That same year, he decided to leave Russia, and there is no doubt that his personal situation, as well as the unrest affecting the whole Academy, affected his assessment of his working conditions in his letter to Celsius.

We learn in a letter written by Delisle in February 1746 to the astronomer Jean-Jacques Marinoni of the Imperial Observatory of Vienna ${ }^{50}$, that "S.M.I. [Sa Majesté Impériale Elisabeth] wished that I should stay a few more years until the problem of the Academy where so many disorders have occurred is solved and the Observatory, which is still very poorly equipped, is in the best possible conditions, a question on which S.M.I. has already given her orders". Following the Empress' proposal, Delisle set out his conditions for remaining in Russia, which he summarised in a letter to the Senate in September of the same year $^{51}$. The first and main condition was that "the Academy was regulated in such a way that the chancellery had no power over the professors or over all things that should concern the sciences or even the economy of the Academy"; he thus expresses his rejection of Schumacher's authority. The second condition related to the staff attached to the Academy, and in particular student interpreters, whose services he wished to avail of; according to Delisle these translators had been diverted by the Chancellery to other tasks. He specified that he was making this request not only for the Astronomy Department, but also for the Geography Department. The third condition concerned the post of Professor of the Marine Academy which he had applied for following Farquharson's death in December 1739. He felt that he was entitled to the position since it was he who, since Farquharson's death, had "instructed in practical and theoretical astronomy the principal masters and sub-masters of this Academy".

${ }^{49}$ Delisle, Joseph-Nicolas (1688-1768), "Lettre de Joseph-Nicolas Delisle à Leonhard Euler, StPétersbourg,7 septembre 1743," Bibliothèque numérique - Observatoire de Paris, consulted 12 February 2021, https://bibnum.obspm.fr/ark:/11287/2ZQdB.

${ }^{50}$ Delisle, Joseph-Nicolas (1688-1768), "Lettre de Joseph-Nicolas Delisle à Giovanni Giacomo Marinoni, St-Pétersbourg, 26 février 1746," Bibliothèque numérique - Observatoire de Paris, consulted 14 February 2021, https://bibnum.obspm.fr/ark:/11287/2JcDW.

${ }^{51}$ Delisle, Joseph-Nicolas (1688-1768), "Lettre de Delisle, le 12 septembre 1745" Bibliothèque numérique - Observatoire de Paris, consulted 14 February 2021, https://bibnum.obspm.fr/ark:/11287/2pSZS. 
In a letter addressed in 1758 to Count Shuvalov ${ }^{52}$, Minister of Education under Empress Elizabeth, Delisle explained that the Empress had testified "in July 1745 to His Excellency Bishop Count Vorontsov, then Vice-Chancellor of the Empire, that she would be happy if I stayed longer in Russia; after having given me the grace to promise that she would remedy the abuses I had represented to her, which had been introduced into the Academy". But on 13 January 1747, just as the new contract was about to be signed, the President of the Academy of Sciences, the recently appointed Count Alexis Grigorievitch Razoumovski, abruptly notified Delisle that he must leave. As he was leaving Russia, he was prevented by Alexis Petrovitch Bestuzhev, Great Imperial Chancellor of Russia, from seeing the Empress; clearly this was a deliberate move to prevent the Empress, who was not aware of his expulsion (at least that is what Delisle thought), from ordering his retention in St-Petersburg. The reasons that led Bestoujev to expel Delisle, through his ally Razoumovski, were probably political in nature, linked to the relations that Delisle, like other scholars expelled under the same conditions (such as Sanches), had with Count Lestocq, the empress's doctor. The latter, an intriguer and author of a foiled conspiracy against Bestoujev, had been, along with the French ambassador La Chétardie, the instigator of the coup d'état that placed Elizabeth on the throne in 1741.

Following the difficulties in the operation of the Academy, a new set of rules was instituted in June 1748. The period which then began saw a diversification of astronomical investigations, with both a slowing down of research, but also the emergence of a new generation of Russian academics ${ }^{53}$. Under the impetus of Lomonosov, who was hired as a resident assistant in 1742, Russian scientists were integrated into the Academy. It was not until Euler's return to StPetersburg in 1766 that astronomy regained its vigour, tripling the space devoted to it in the Academy's proceedings at that time.

\subsection{Correspondence with Anders Celsius and Pehr Wilhelm Wargentin at the Uppsala Observatory (1742-1751)}

\footnotetext{
52 Delisle, Joseph-Nicolas (1688-1768), "Lettre de Joseph-Nicolas Delisle à Pierre Ivanovitch Chouvalov, Paris, 6 juillet 1758," Bibliothèque numérique - Observatoire de Paris, consulted 14 February 2021, https://bibnum.obspm.fr/ark:/11287/gLFtt.

${ }^{53}$ Sigrist, op. cit. (ref. 1), p. 106-108.
} 


\subsubsection{Context}

The history of the Royal Society of Sciences in Uppsala is closely linked to that of Anders Celsius, who was the driving force behind it and who also founded the Uppsala Observatory. Celsius' grandfather, Anders Spole, was a renowned astronomer who travelled to all the major astronomical centres of Europe ${ }^{54}$. He settled in Uppsala, where he obtained a position as professor of astronomy in 1679. The observatory that Spole had built there was destroyed by fire shortly after his death in 1699. The young Anders Celsius, born two years later, decided in his turn to become an astronomer. In 1719 , at the age of 18 , he joined a scientific society called Bokvettsgillet, literally "the society of the wisdom of the book". This society was founded by Erik Benzelius ${ }^{55}$, librarian at the University of Uppsala, who in 1742 became archbishop and pro-chancellor of the university. Celsius became secretary of the Society in 1725. He spent some time in Stockholm, then returned to Uppsala. On November 11, 1728, the Society, after receiving a royal charter, was transformed into the Societas Regia Litteraria et Scientiarum, or more simply the Royal Society of Sciences. In 1729, Celsius became Professor of Mathematics and Physics at the University of Uppsala. Between 1732 and 1737, he made a long tour of European observatories, which he concluded with his participation in the Lapland expedition led by Maupertuis to measure the shape of the Earth. During this period, the activities of the Royal Society ceased almost completely.

On his return, Celsius revived the Society with the help of Olof Hiorter, who officially became his assistant in this task. On January 15, 1742, the Royal Society of Uppsala presented the king with a project signed by eight of its scholars, including Celsius and Hiorter, aimed at electing, in addition to its members, a small number of honorary members, as well as twelve foreign scholars as corresponding members. The Society had three paid officials: the Secretary, the Treasurer and the Librarian. The work of the Society was published in an annual journal, which appeared until 1751 but which was then discontinued for the next twenty years due to a lack of both scientific work to be published and financial resources. The lack of means was a recurrent situation that Benzelius, and later Celsius, had to face. In 1716,

\footnotetext{
${ }^{54}$ H. C. Stempels, “Anders Celsius' contributions to meridian arc measurements and the establishment of an astronomical observatory in Uppsala", Baltic astronomy, 20 (2011), 179-185.

${ }^{55}$ Olof Glass, Essai sur la Société Royale des Sciences d'Upsal et ses rapports avec l'Université d’Upsal (Upsal, Berling, 1877).
} 
Benzelius had obtained the Queen's permission to dig up and sell cast iron water pipes that had become unusable, which brought the company some money. In 1725, Benzelius tried to convince the king to grant the company the exclusive right to make and sell calendars, as practiced at the Prussian Academy, a monopoly which would result in "greater accuracy in the indications of these almanacs and the elimination of all unfounded conjecture leading to the superstition usually found in them". But this request, even with the progressive argument used by Benzelius, a request reformulated in 1738, never came to fruition and the Society's financial situation remained precarious; the Acts of the Society, for example, were published at the expense of its members.

The proximity between the University and the Royal Society in the same city facilitated exchanges between the two institutions and explains the strong influence they exerted on each other. The influence of the University on the Royal Society is directly reflected in the fact that the members of the Society were professors of the University, paid by the University. The University in turn brought added value to the Society, of which the creation of the Astronomical Observatory was an essential element. The attempts of Benzelius, in 1716, and then of the astronomer Erik Burman, in 1723, to obtain the necessary means for the construction of the observatory were unsuccessful, but they had the merit of drawing the attention of the government and the University's Academic Council to the project. It was in 1738 that Celsius took steps with the Senate of the University to obtain the necessary grants for the construction of an observatory ${ }^{56}$. At the same time, Celsius had a clock and a sector made in London by Graham and delivered to him in Uppsala, for which he obtained funding from the university. The building was also financed and constructed in two years. The Observatory became operational in 1742 but unfortunately Celsius had little time to enjoy it as he died two years later. Olof Hiorter succeeded him as Director of the Observatory, assisted by Pehr Wilhelm Wargentin, another follower of Celsius.

\subsubsection{The obstacles encountered by Pehr Wilhelm Wargentin}

\footnotetext{
${ }^{56}$ Martin Ekman, “The Man behind 'Degrees Celsius':: a Pioneer in Investigating the Earth and its Changes", Summer Institute for Historical Geophysics (2016), p. 71-75.
} 
In a letter of January $1742^{57}$, Celsius told Delisle of his satisfaction at having an operational observatory: "My Observatory is now in fairly good order, and I am at ease there". He describes the sector built by Graham, and mentions the very precise clock supplied by the same manufacturer, both instruments having also been made under the guidance of James Bradley, then Director of the Greenwich Observatory. He mentioned that he was expecting a "transit instrument" to be made by Ekström in Stockholm the following summer. After Celsius' death, Delisle corresponded with Wargentin. In a letter from March $1745^{58}$, Wargentin, then aged 27, explained to Delisle that he had made observations during Celsius' lifetime, but that he had no money to buy instruments, and that to earn his living he had to become a tutor, which took up a lot of his time. In a letter of February $1748^{59}$ Wargentin describes the reason why he had not been able to use the instruments of the Observatory. He wrote: "For me, I have enough leisure and strength to observe, so that I would do nothing better than to occupy myself with such useful work. But one is not allowed to be at the Observatory alone. I can only enter when Mr. Hiorter goes there himself. So the instruments, which Mr. Celsius selected with such care, remain unused". So it was Hiorter, the guardian of the premises, who prevented Wargentin from working at the Observatory. Moreover, Wargentin laments how almost no more observations were being made at the Observatory because Hiorter was "in charge of a commission, which almost entirely steals him from the observations". In a letter of November 1748, Delisle ${ }^{60}$ complained to Wargentin about the little information he received about Hiorter's observations, which he attributed to the latter's uncommunicative nature. He told Wargentin that if he communicated the results of Hiorter's observations to him, he would make "no public use" of these elements.

${ }^{57}$ Celsius, Anders (1701-1744), "Lettre de Anders Celsius à Joseph-Nicolas Delisle, Uppsala, 5 janvier 1742," Bibliothèque numérique - Observatoire de Paris, consulted 12 February 2021, https://bibnum.obspm.fr/ark:/11287/3mSHT.

${ }^{58}$ Wargentin, Pehr Wilhelm (1717-1783), "Lettre de Pehr Wilhelm Wargentin à Joseph-Nicolas Delisle, Diurbÿ, 27 mars 1745," Bibliothèque numérique - Observatoire de Paris, consulted 12 February 2021, https://bibnum.obspm.fr/ark:/11287/xXpXt.

${ }^{59}$ Wargentin, Pehr Wilhelm (1717-1783), "Lettre de Pehr Wilhelm Wargentin à Joseph-Nicolas Delisle, Uppsala, 27 février 1749," Bibliothèque numérique - Observatoire de Paris, consulted12 February 2021, https://bibnum.obspm.fr/ark:/11287/qJGkS.

${ }^{60}$ Delisle, Joseph-Nicolas (1688-1768), "Lettre de Joseph-Nicolas Delisle à Pehr Wilhelm Wargentin, Paris, 6 décembre 1748," Bibliothèque numérique - Observatoire de Paris, consulted 12 February 2021, https://bibnum.obspm.fr/ark:/11287/13mf8. 
We learn in a letter from Wargentin in June $1745^{61}$ that the construction of the transit instrument mentioned in Celsius's letter of January 1742 had been completed by Ekström. At the same time it is stated that Celsius' death had interrupted the construction of a large wall quarter-circle made by the Swedish craftsman. It must be concluded either that Hiorter did not have the will to have this instrument made, or that he did not have sufficient weight with the University authorities to obtain the required financing. At the end of 1749, Delisle wrote to Wargentin $^{62}$ that he was ready, as a member of the Academy of Uppsala, as well as of the Academy of Stockholm, to intervene directly with the hierarchies of these institutions to request that Hiorter grant Wargentin access to the Uppsala Observatory. Hiorter died in 1750 and we learn in a letter from Wargentin in November $1749^{63}$ that "the Academy had an Observatory built in Stockholm, whose situation was infinitely more advantageous than that of the Observatory in Uppsala. The Academy will spare no expense either to provide me with the instruments necessary to observe the stars well". He explains that the Stockholm Observatory would not be operational for another two years (in fact, the building would not be completed until 1753), but that in the meantime he would not fail to make observations with the "few instruments" he already had. In a letter of March $1751^{64}$, Wargentin described the success of the request to the king for means to acquire instruments to support the Swedish observation campaign that was being coordinated with that of De la Caille at the Cape of Good Hope; in fact the endowment allocated to the Academy of Stockholm exceeded the amount requested. The manufacturer Ekström was heavily involved in the production of

${ }^{61}$ Wargentin, Pehr Wilhelm (1717-1783), "Lettre de Pehr Wilhelm Wargentin à Joseph-Nicolas Delisle, Diurbÿ, 12 juin 1745," Bibliothèque numérique - Observatoire de Paris consulted 12 February 2021, https://bibnum.obspm.fr/ark:/11287/3ndct.

${ }^{62}$ Delisle, Joseph-Nicolas (1688-1768), "Lettre de Joseph-Nicolas Delisle à Pehr Wilhelm Wargentin, Paris, 5 décembre 1749," Bibliothèque numérique - Observatoire de Paris, consulted 12 February 2021, https://bibnum.obspm.fr/ark:/11287/M2Xkk.

${ }^{63}$ Wargentin, Pehr Wilhelm (1717-1783), "Lettre de Pehr Wilhelm Wargentin à Joseph-Nicolas Delisle, Stockholm, 28 novembre 1749," Bibliothèque numérique - Observatoire de Paris, consulted 12 February 2021, https://bibnum.obspm.fr/ark:/11287/11jCC.

${ }^{64}$ Wargentin, Pehr Wilhelm (1717-1783), "Lettre de Pehr Wilhelm Wargentin à Joseph-Nicolas Delisle, Stockholm, 16 mars 1751,” Bibliothèque numérique - Observatoire de Paris, consulted 12 February 2021, https://bibnum.obspm.fr/ark:/11287/2LVMX. 
instruments for this campaign. It was therefore in Stockholm that Celsius's torch was taken up by his pupil Wargentin, Permanent Secretary of the Stockholm Academy from 1749 until his death in 1783, and first Director of the Academy's Observatory.

\section{Discussion}

Table 1 below summarises the obstacles encountered in the four academies studied.

Table 1: Obstacles encountered in the four academies

\begin{tabular}{|c|c|c|c|c|}
\hline $\begin{array}{l}\text { Obstacles } \\
\text { appearing in } \\
\text { Delisle's } \\
\text { correspondence }\end{array}$ & Berlin & Bologna & St-Petersburg & Uppsala \\
\hline Low salary & $\begin{array}{l}\text { Lack of } \\
\text { international } \\
\text { attractiveness }\end{array}$ & $\begin{array}{l}\text { Time spent on } \\
\text { astronomy } \\
\text { reduced by time } \\
\text { spent on other } \\
\text { remunerative } \\
\text { functions }\end{array}$ & & $\begin{array}{l}\text { Time spent on } \\
\text { astronomy } \\
\text { restricted by } \\
\text { cumulation with } \\
\text { other income- } \\
\text { generating } \\
\text { functions }\end{array}$ \\
\hline $\begin{array}{l}\text { Absence or } \\
\text { inadequacy of } \\
\text { recurrent } \\
\text { resources }\end{array}$ & $\begin{array}{l}\text { Poorly performing } \\
\text { and/or obsolete } \\
\text { instruments }\end{array}$ & $\begin{array}{l}\text { Poorly performing } \\
\text { and/or obsolete } \\
\text { instruments }\end{array}$ & & $\begin{array}{l}\text { Lack of } \\
\text { instrument }\end{array}$ \\
\hline $\begin{array}{l}\text { Time-consuming } \\
\text { service tasks }\end{array}$ & $\begin{array}{l}\text { Realization of } \\
\text { calendars }\end{array}$ & & $\begin{array}{l}\text { Cartography of } \\
\text { Russia }\end{array}$ & \\
\hline $\begin{array}{l}\text { Insufficient } \\
\text { support from } \\
\text { political power }\end{array}$ & $\begin{array}{l}\text { Reign of Friedrich } \\
\text { Wilhelm I and } \\
\text { Silesian Wars }\end{array}$ & $\begin{array}{l}\text { Direct steering of } \\
\text { the Academy by } \\
\text { the Bologna } \\
\text { Senate without } \\
\text { scientific vision }\end{array}$ & & $\begin{array}{l}\text { Lack of visibility } \\
\text { of astronomy vis- } \\
\text { à-vis political } \\
\text { power }\end{array}$ \\
\hline $\begin{array}{l}\text { Conflicts of } \\
\text { power }\end{array}$ & & & $\begin{array}{l}\text { Multiple political } \\
\text { rivalries } \\
\text { disrupting the } \\
\text { proper exercise of }\end{array}$ & $\begin{array}{l}\text { "Privatisation" of } \\
\text { the Uppsala } \\
\text { Observatory for } \\
\text { the benefit of a }\end{array}$ \\
\hline
\end{tabular}




\begin{tabular}{|l|l|l|l|l|}
\hline & & & science & single astronomer \\
\hline
\end{tabular}

We will now comment on and characterize these different obstacles.

\subsection{Astronomer's salaries}

The low salaries of astronomers in some observatories resulted, on the one hand, in a lack of attractiveness which did not allow the recruitment of quality astronomers at the international level, as recounted by Euler in the case of the Berlin Observatory, and on the other hand, in a reduction in the time devoted to astronomy due to the exercise of other remunerated activities, such as Manfredi's position as Water Superintendent in Bologna, or the ancillary activities of Wargentin and Hiorter in Uppsala. It is interesting to examine objectively the levels of salaries in the four observatories studied, and to compare them to the levels of remuneration in Paris and Greenwich, two major European observatories created in the 17th century.

Jean-Dominique Cassini's annual salary, fixed when he joined the Paris Observatory in 1669, was 9000 pounds ("Livres tournois", denoted by L in the following) 65 . From 1689, the salaries of astronomers, including Cassini, were reduced to a third due to the depletion of the royal treasury by military expenditure. In 1690, they only received advance payments, and in the following years their salaries ceased to be paid ${ }^{66}$. The salary of Jacques Cassini, who took over from his father in 1712, was $3000 \mathrm{~L}$, the level of remuneration of the most senior member of each class of the Royal Academy of Sciences ${ }^{67}$ (here the Astronomy class). The first official Director of the Observatory, Cassini de Thury, appointed in December 1771, was also paid $3000 \mathrm{~L}^{68}$. The salary of the first Director of the Greenwich Observatory, John Flamsteed, was $£ 100$ per year ${ }^{69}$. Edmund Halley, who succeeded him in 1727 , started on the same salary, but saw it increased to $£ 350$ in 1727 . James Bradley, who succeeded Halley in

${ }^{65}$ C. Wolf, Histoire de l'Observatoire de Paris de sa fondation à 1793 (Paris, Gauthier-Villars, 1902), p. 199.

${ }^{66}$ Wolf, op. cit. (ref. 65), p. 209.

${ }^{67}$ Roger Hahn, "Scientific Research as an Occupation in Eighteenth-Century Paris", Minerva, 13 (Winter 1975), 501-513, p. 507.

${ }^{68}$ Wolf, op. cit. (ref. 65), p. 232.

${ }^{69}$ Paul Ditisheim, «L’Observatoire Royal de Greenwich», Société Astronomique de France, décembre 1925, John G. Wolbach Library, Harvard-Smithsonian Center for Astrophysics. 
1742, was initially paid $£ 100$ and then $£ 350$ from 1752 onwards, a level of pay that continued to be enjoyed by his successors ${ }^{70}$.

Gottfried Kirch was hired at the Royal Observatory in Berlin in 1700 for an annual salary of 400 thalers $^{71}$. Christfried Kirch, in charge of the Observatory from 1716, and appointed astronomer in 1728, also received 400 thalers, then 500 thalers from 1735 onwards $^{72}$. At the Bologna Institute, Eustachio Manfredi took over the direction of the Observatory in 1711, a position he handed over to Eustachio Zanotti on his death in 1739. Manfredi was a professor of mathematics at the University of Bologna, as was Laura Bassi who, when she started in 1732, was paid an annual salary of 500 lire $^{73}$. At the Institute, the salaries of the President and the Secretary in the early 1760s were 800 lire $^{74}$, which seems to be an upper limit for the salary of the Director of the Observatory, which was therefore between 500 and 800 lire. The initial salary of Joseph-Louis Delisle in St-Petersburg was 1800 rubles $^{75}$. In a letter to Count Vorontsov in December 1755, Delisle indicated that his salary in 1747, at the end of his stay in Russia, was 800 rubles for a tertial ${ }^{76}$, i.e. 2400 rubles a year. The Director of the Royal Observatory of Uppsala, Anders Celsius, appointed professor of astronomy in 1730 at the University of Uppsala, received a salary of 2100 copper dalers per year, or $£ 52.5^{77}$. The values of the salaries of the Observatory directors, converted into pounds, are shown in the last column of Table 2 below:

70 Civil List Funding (1752-1875), The Royal Observatory Greenwich, http://www.royalobservatorygreenwich.org/articles.php? article $=960$.

${ }^{71}$ Roland und Ute Wielen, Johann Elert Bodes Geschichte der Berliner Sternwarte bis zum Jahr 1811 (Heidelberg, Edition der Handschrift, 2010), p. 58.

${ }^{72}$ Alphonse des Vignoles, «Éloge de M. Kirch le fils, Astronome de Berlin », Journal littéraire d'Allemagne, de Suisse et du Nord, Tome Premier (La Haye, 1741), 300-351, p. 337.

${ }^{73}$ Scienza a Due Voci, http://scienzaa2voci.unibo.it/biografie/70-bassi-veratti-laura-maria-caterina.

${ }^{74}$ Alberto Elena, “'In lode della filosofessa di Bologna': An Introduction to Laura Bassi”, Isis 82, 3 (1991), 510-518, p. 514.

${ }^{75}$ Jean Marchand, "Le départ en mission de l'astronome J.-N. Delisle pour la Russie (1721-1726) ", Revue d'Histoire Diplomatique (Paris, Berger-Levrault, 1929), p. 388.

${ }^{76}$ Delisle, Joseph-Nicolas (1688-1768), "Lettre de Joseph-Nicolas Delisle à Mikhaïl Illarionovitch Vorontsov, Paris, 29 décembre 1755," Bibliothèque numérique - Observatoire de Paris, consulted 11 February 2021, https://bibnum.obspm.fr/ark:/11287/1kvb3.

${ }^{77}$ Ekman, op. cit. (ref. 56), p. 72-73. 
Table 2: Salaries of the directors of the six observatories ${ }^{78}$.

\begin{tabular}{|l|l|l|l|}
\hline Observatory & $\begin{array}{l}\text { Salary in the 18th } \\
\text { century }\end{array}$ & Exchange rate & Amount in pounds \\
\hline Paris (1667) & 3000 pounds & 1 & 3000 \\
\hline Greenwich (1675) & $100-350 £$ & $15^{79}$ & $1500-5250$ \\
\hline Berlin (1700) & $400-500$ thalers & $3^{80}$ & $1200-1500$ \\
\hline Bologna (1725) & $500-800$ lire & $0,9^{81}$ & $450-720$ \\
\hline St-Petersburg (1726) & $1800-2400$ rubles & $5^{82}$ & $9000-12000$ \\
\hline Uppsala (1741) & 2100 copper dalers & 0,37 & 780 \\
\hline
\end{tabular}

With the exception of Delisle, these levels of remuneration were moderate or low. Hahn estimates that in the middle of the 18th century, an annual income of 5,000 livres was barely enough to live well in Paris ${ }^{83}$. Knowing that these astronomers were housed in their observatories, their financial situation can be considered excellent in St-Petersburg, good in London and to a lesser extent in Paris, and clearly bad in Uppsala, Bologna and Berlin.

\footnotetext{
${ }^{78}$ For observatory directors who were also professors at the university where their observatory was located, such as Manfredi in Bologna or Celsius in Uppsala, these salaries corresponded to their professorial salaries, as these scientists do not appear to have received any additional specific remuneration linked to their position as observatory director. Halley, at Greenwich, combined his position as director of the observatory with that of professor of geometry at Oxford, and it is possible, if not probable, that a professor's salary was added to his salary as director of the observatory. For those who were not professors, such as Cassini in Paris, Kirch in Berlin and Delisle in St Petersburg, their salary was directly linked to their position as director of the observatory, and constituted their only source of income, at least in the academic sphere.

${ }^{79}$ Alexandre de Chambrier, "Évaluation de la livre tournois et des principales monnaies en usage dans les pays du refuge 1685-1715", Bulletin de la Société de l'Histoire du Protestantisme Français (19032015) 58, 1 (1909), p. 77.

${ }^{80}$ Chambrier, op. cit. (ref. 79), p. 76-77.

81 Lalande, op. cit. (ref. 28), p. 63. 2,000 Scudi, that is 12,000 Lire (cf https://fr.wikipedia.org/wiki/Scudo), represent 10,667 L.

${ }^{82}$ Marie-Anne Chabin, Les français et la Russie dans la première moitié du XVIII ${ }^{\text {ème }}$ siècle. La famille Delisle et les milieux savants, Thèse pour le diplôme d'archiviste-paléographe (1983), p. 75.

${ }^{83}$ Hahn, op. cit. (ref. 67), p. 507.
} 


\subsection{Means for the acquisition of observation instruments}

The instrument stocks of some observatories were particularly deficient, either because the instruments were imprecise and/or ageing, as was the case in Berlin and Bologna until the 1740s or even beyond, or because they had very few instruments in the absence of significant support from academic or political authorities, as in Uppsala. It is useful to make a comparison between the levels of equipment expenditure of these observatories, including the Paris and Greenwich Observatories in the comparison as before.

The Royal Observatory of Paris, which cost 714,000 L to construct, was not provided with an annual rent by Colbert (First Minister of State under Louis XIV) to allow for the maintenance and regular renewal of the instruments ${ }^{84}$. At the beginning of 1682, while the last finishing touches were being made to the Observatory building, Cassini drew up a list of instruments to be acquired ${ }^{85}$. Expenditure on mathematical instruments, like quarter-circles, globes and clocks, mainly between 1668 and 1688, amounted to 38,000 L, while expenditure on optical instruments for telescopes and their supports, including telescopes themselves, during the same period was $26,000 \mathrm{~L}$. Adding to this the expenditure on clocks and watches, the total investment in equipment for the Observatory in the 17th century was of the order of 70,000 L. In the 18th century, acquisitions, financed by the Academy's funds, were more modest with the addition of a few instruments and their domes, since the Observatory's main building was not very suitable for the use of these instruments. A first dome was added in 1730, and equipped in the following decade, for a total cost of $8000 \mathrm{~L}$. Two other domes were installed later, the three domes having to be rebuilt in 1776 due to a lack of maintenance because of insufficient financing. The cost to the State probably did not exceed 20,000 L, and the overall expenditure in the 17th and 18th centuries was of the order of $90,000 \mathrm{~L}$; in fact most of the instruments purchased had previously been used for distant measurement campaigns and were either deteriorated or were recovered by the astronomers who used them for their private observatories, and so did not remain usable at the Observatory for long. The Greenwich Observatory, built at a cost of $£ 500^{86}$, also lacked funds for the acquisition and maintenance

\footnotetext{
${ }^{84}$ Wolf, op. cit. (ref. 65), p. 135-193.

${ }^{85}$ Wolf, op. cit. (ref. 65), p. 149-150.

${ }^{86}$ History of The Royal Observatory, https://www.the-observatory.org/rgohistory.
} 
of instruments. Flamsteed had to have its instruments built at his own expense, and a few instruments were received from donors. After his death, Flamsteed's heirs demanded the return of the instruments that he had paid for personally. Halley, who found the Observatory empty when he moved there a few months later in 1720, obtained a $£ 500$ grant from the King to equip it ${ }^{87}$. Twenty years later, his successor Bradley was awarded $£ 1,000$ to renew the instruments. The instruments set up by these two astronomers constituted the bulk of the Observatory's equipment throughout the 18th century.

The income of the Berlin Academy, mainly gleaned from the sale of calendars, was in the order of 2,500 thalers per year in the early 1700s, and rose to 19,000 thalers in the $1770 \mathrm{~s}$, thanks to the increase in profit from the sale of calendars for Silesia ${ }^{88}$ from 1746 onwards. The first valuable instrument used in Berlin was the wall quarter-circle ordered from the English manufacturer John Bird in 1768, costing around $8000 \mathrm{~L}^{89}$. The observation instruments used previously ${ }^{90}$ were of low value, and the overall value of equipment can be estimated at $10,000 \mathrm{~L}$. The sum allocated in 1712 by the Vatican for the construction of the new Bologna Institute of Sciences, including the cost of building the Observatory, was 24,000 Scudi $^{91}$. The annual income of the Institute was 2000 Scudi $^{92}$. The instruments acquired in 1742 were a wall-mounted quarter-circle, a mobile quarter-circle and a transit telescope, all made by Georges Graham in London. The wall-mounted quadrant can be estimated at $5000 \mathrm{~L}$, the mobile quadrant at $1000 \mathrm{~L}^{93}$, and the transit telescope at $1000 \mathrm{~L}^{94}$. The overall expenditure on equipment, including the instruments used before the 1742 purchases, is again of the order of $10,000 \mathrm{~L}$. The array of equipment at the Observatory of St-Petersburg in 1738 consisted of
87
The
Royal
Observatory
Greenwich,

http://www.royalobservatorygreenwich.org/articles.php?article=1053.

${ }^{88}$ Londa Schiebinger, "Maria Winkelmann at the Berlin Academy: A Turning Point for Women in Science", Isis, 78, 2 (1987), 174-200, p. 184.

${ }^{89}$ Turner op. cit. (ref. 7), p. 375.

${ }^{90}$ Journal littéraire de l'année M. DCC. XV., tome septième, première partie (La Haye, 1738), p. 188.

${ }^{91}$ Christopher M. S. Johns, "Art and Science in Eighteenth-Century Bologna: Donato Creti's Astronomical Landscape Paintings", Source: Zeitschrift für Kunstgeschichte, 1992, 55. Bd., H. 4 (1992), 578-589, p. 581.

${ }^{92}$ Lalande, op. cit. (ref. 28), p. 63.

${ }^{93}$ Turner op. cit. (ref. 7), p. 375.

${ }^{94}$ The Royal Observatory Greenwich op. cit. (ref. 87). 
about twenty instruments: an English wall sextant, an English mobile sextant, two mobile quarter circles, three Newtonian telescopes, two telescopes by Campani, three sighting telescopes, and several clocks built in Paris and London ${ }^{95}$. The total value of these instruments, all destroyed in the fire of 1747 , must have been of the order of $12,000 \mathrm{~L}$. A wall-mounted quarter circle and an English transit telescope were purchased in 1760, representing an expenditure of about 10,000 L. The overall expenditure to equip the StPetersburg Observatory between 1725 and 1760 was thus about 22,000 L (4,400 rubles), the equivalent of about two years of Delisle's salary. It should be noted that Empress Elisabeth was prepared to invest 6,000 rubles in 1745 to keep Delisle at the Observatory ${ }^{96}$. The annual endowment of the Imperial Academy of Sciences of St-Petersburg increased from 25,000 rubles in $1724^{97}$, when it was founded, to 53,000 rubles in $1748^{98}$. The total cost of building and equipping the Uppsala Observatory was 33,000 copper daler ${ }^{99}$. The instrumentation consisted of a quadrant bought in Paris worth 3000 dalers, as well as two instruments bought from George Graham in London - a sector worth 4000 dalers and a clock worth 1200 dalers amounting to a total cost of around 8000 dalers.

This information is summarised in Table 3 below, after conversion into "Livres tournois", using the exchange rates reported in Table 2. We did not find any information on the costs of setting up the Berlin and St-Petersburg observatories.

Table 3: Building and equipment expenditure for the six observatories and incomes of the academies to which they belonged.

\begin{tabular}{|l|l|l|l|}
\hline Observatory & $\begin{array}{l}\text { Expenditure on } \\
\text { construction (L) }\end{array}$ & $\begin{array}{l}\text { Expenditure on } \\
\text { equipment (L) }\end{array}$ & $\begin{array}{l}\text { Annual income of } \\
\text { the Academy (L) }\end{array}$ \\
\hline Paris (1667) & 700000 & 90000 & 42000 \\
\hline
\end{tabular}

${ }^{95}$ Struve, op. cit. (ref. 46), p. 7.

${ }^{96}$ Delisle, Joseph-Nicolas (1688-1768), "Lettre de Joseph-Nicolas Delisle à Pierre Ivanovitch Chouvalov, Paris, 6 juillet 1758," Bibliothèque numérique - Observatoire de Paris, consulted 14 February 2021, https://bibnum.obspm.fr/ark:/11287/gLFtt.

${ }^{97}$ See, for example, Leonov, op. cit. (ref. 48), p. 75.

98 "Nouvelles littéraires, Russie, de S. Petersbourg", Journal des savants pour l'année M. DCC. XLVIII. Janvier (Paris, Gabriel-François Quillau, 1748), 500-507.

${ }^{99}$ Ekman, op. cit. (ref. 56), p. 72-73. 


\begin{tabular}{|l|l|l|l|}
\hline Greenwich (1675) & $7500^{*}$ & 22500 & 0 \\
\hline Berlin (1700) & - & 10000 & $7500-57000$ \\
\hline Bologna (1725) & $<130000$ & 10000 & 10600 \\
\hline St-Petersburg (1726) & - & 22000 & $125000-250000$ \\
\hline Uppsala (1741) & 10000 & 3000 & 0 \\
\hline
\end{tabular}

* In addition to this sum, the observatory received wood, iron and lead from a demolished guardhouse at the Tower of London, and "spare bricks from Tilbury Fort".

Of the four observatories studied, only St-Petersburg is comparable to Paris and Greenwich in terms of the resources available to its astronomers. Of the three academies concerned, the London Academy was not financed by the State, and the Paris Academy was only financed to the tune of $12,000 \mathrm{~L}$ for experiments, with the remaining $30,000 \mathrm{~L}$ being for salaries. The instruments purchased for Greenwich and, in the 17th century, for Paris were financed from the royal treasury, while the equipment purchased in the 18th century in Paris was financed from the Academy's budget. In St-Petersburg, the instruments were financed from the Academy's recurrent credits. The considerable cost of the Paris Observatory, which was little used for observation after the death of Jean-Dominique Cassini in 1712, reflects Louis XIV's desire to make this Observatory a brilliant showcase for French astronomy. The equipment of the three other observatories, Berlin, Bologna and Uppsala, remained modest, even after the purchase of English instruments in the mid-18th century.

\subsection{Service activities}

Leibniz's decision to bring Gottfried Kirch to Berlin in 1700 was mainly guided by Kirch's reputation as a producer of calendars. As an astronomer in Leipzig at the time, Kirch began in 1681 "to publish ephemerides, which contained not only what we see in the ordinary calendars, but also the movements of all the planets, their rising, \& setting, their situation in Heaven, their aspects, \&c." ${ }^{100}$, in order to support his family. His second wife, Maria Winkelman, whom he married in 1692, was herself an astronomer and helped him with the making of the calendars, although unofficially because the Berlin Academy did not want to

\footnotetext{
${ }^{100}$ Alphonse des Vignoles, "Éloge de Madame Kirch à l'occasion de laquelle on parle de quelques autres Femmes \& d'un Paysan Astronome”, Journal littéraire d'Allemagne, de Suisse et du Nord, Tome Troisième (Amsterdam, Pierre Humbert \& Fils, 1721), 157-186, p. 174-175.
} 
recognise her institutional existence ${ }^{101}$. The income from the calendars was intended to raise the necessary funds for the construction of the Observatory, which would also function as a meeting place for the academicians. The construction of the building took ten years, and it was not operational until 1711. After her husband's death in 1710, Maria Winkelmann was denied access to the Observatory but continued to produce calendars for various booksellers because she had to support her family. She died in 1720, but her son Christfried, the Director of the Observatory from 1716, and her two daughters Christine and Margaretha, took over the production of the calendars. After Christfried's death in 1740, Christine Kirch continued to make calendars, helped at the beginning by Johann Wilhelm Wagner, until her death in 1782 . She became the first woman to be paid by the Berlin Academy at a salary level equivalent to that of her brother (400 thalers per year), because of the vital importance of this activity, which she alone was able to carry out after her brother's death. The production of calendars was thus the main activity of the astronomers who succeeded each other as directors of the Observatory throughout this period.

A significant part of the income of the Imperial Academy of St. Petersburg also came from the sale of calendars ${ }^{102}$. It is known that during the four years he spent at the Academy before his death in 1729, Christoph Friedrich Mayer, one of the two astronomers assisting Delisle at the Observatory, composed a calendar, the first and only one for a long time not to include astrological elements ${ }^{103}$. This activity, although it did not impact on Delisle's workload plan, certainly had a negative impact on the global scientific production of the Observatory, like in Berlin.

Delisle was invited to St-Petersburg mainly to manage the major mapping project of Russia envisaged by Peter the Great. His activity as an astronomer was strongly affected by this, as he confided to Bignon at the beginning of 1730, four years after his arrival, and all the more so as he did not, according to himself, benefit from sufficient support in terms of technical personnel (geodesists, draughtspersons). It was precisely this aspect of his activity that was to fuel the tension that arose in the 1730s between him and the Russian authorities, as he

\footnotetext{
${ }^{101}$ Schiebinger, op. cit. (ref. 88), 174-200.

${ }^{102}$ Ludmilla Schulze, "The Russification of the St. Petersburg Academy of Sciences and Arts in the Eighteenth Century", The British Journal for the History of Science, 18, 3 (1985), 305-335, p. 312.

${ }^{103}$ Sigrist, op. cit. (ref. 1), p. 96.
} 
allowed himself to be overwhelmed by the quantity of information to be processed, and fell behind schedule for the publication of the map ${ }^{104}$. In January 1737, Delisle proposed a project to measure the shape of the Earth in Russia ${ }^{105}$, requiring a triangulation of the whole of Russia from a large base that he had measured completely the same year, probably hoping to obtain, through an operation that he considered to be of great prestige for Russia, the means that he would otherwise be unable to mobilise; unfortunately this project was buried in April 1739 . Delisle's cartographic responsibilities, from which he was relieved the following year, thus absorbed a large part of his time and energy for nearly fifteen years.

\subsection{Political support for science}

In Berlin, the period from 1713 to 1740, corresponding to the reign of Friedrich Wilhelm I, a king who had no interest in the arts and sciences, was described by the Academy as the "cold season for the sciences"106. The publication of the Academy's memoirs, revived in 1735 by Jablonski and Viereck, nevertheless led to the printing of three volumes between 1734 and 1744, as many as in the first thirty years of the Academy's life. Each of these volumes contained astronomical observations worth "a fine reputation to the most useful members of the company at the time, to the astronomers whose ephemerides and calendars were, until 1740, the Academy's only assured resource". Observations were nevertheless made with deficient instruments, as Wagner described in his correspondence with Delisle. After the advent of Friedrich II, the Observatory was for a time threatened with destruction. The three Silesian Wars between 1740 and 1763 between Prussia and Austria monopolised the attention and finances of the King of Prussia. It was only in 1764, five years after the death of Maupertuis, president of the Academy from 1745 to 1759, that Friedrich, anxious to develop the sciences, posed himself "not only as Protector, but as supreme Director, as high

\footnotetext{
${ }^{104}$ Michel Mervaud, "Voltaire et l'Académie des sciences de St-Pétersbourg. La correspondance de Voltaire avec Kirill Razumovskij à la lumière du conflit entre Joseph-Nicolas Delisle et l'Académie des sciences de St-Pétersbourg", Revue des études slaves, 80, 4 (2009), 459-471.

105 Joseph-Nicolas Delisle, "Projet de Mesure de la Terre en Russie, lu dans l'Assemblée de l'Académie des Sciences de St Petersbourg, le 21 janvier 1737, À St Petersbourg, de l'Imprimerie de l'Académie des Sciences, 1737" Bibliothèque Germanique, ou Histoire Littéraire de l'Allemagne, de la Suisse, et des Pays du Nord, Année MDCCXXXVII, Tome XXXIX (Amsterdam, Pierre Humbert, 1737).

${ }^{106}$ Bartholmess, op. cit. (ref. 9), p. 121-124.
} 
administrator of the Academy, as its Curator" ${ }^{107}$. Jean Bernoulli, the third in a famous line of Basel scholars, was appointed the same year by Friedrich as Director of the Observatory, which was soon to be equipped with a latest-generation instrument made in London ${ }^{108}$.

Placing the Academy of Bologna under the direct supervision of the city's Senate prevented the scientific development of the institution, as Marsigli noted ${ }^{109}$ when he returned to Bologna in 1723, considering that the Institute had failed in several respects. In particular, the Bolognese did not attend the lectures or experimental demonstrations given at the Institute; they only came to accompany foreign visitors, the Institute having only a ceremonial role. Moreover, several requests initially made by Marsigli, which had been a condition of the donation he had made ten years earlier, were not respected. Marsigli's list of grievances was sent not only to the Senate, but also, through the Archbishop of Bologna Lambertini, to the Pope, who in August 1726 gave a favourable response. During the 1730s, Eustachio Manfredi, the Director of the Observatory, assisted by his successor Eustachio Zanotti, lobbied for the necessary funds from Rome to buy good instruments ${ }^{110}$. With the assistance of Sir Thomas Dereham, an English Catholic resident in Rome who facilitated contacts between Italian scholars and the Royal Society, a wall quadrant, a mobile quadrant and a transit telescope were ordered in 1738 from George Graham and his assistant Jonathan Sisson in London. The role of Lambertini, who became pope in 1740, in granting resources to the Academy of the Bologna Institute, was obviously decisive, not only for astronomy, but for all the scientific and artistic disciplines represented at the Academy, with numerous grants and donations made during the eighteen years of his pontifical mandate. At the Observatory, Zanotti, who had been its director since 1739, the year of Manfredi's death, took particular care to furnish the Meridian Hall, where he installed the transit telescope in August 1742, and spent a further year calibrating the instruments, the whole becoming operational in 1743.

\footnotetext{
${ }^{107}$ Bartholmess, op. cit. (ref. 9), p. 206.

${ }^{108}$ Dick, op. cit. (ref. 14), p. 527.

${ }^{109}$ Dragoni, op. cit. (ref. 30), p. 234.

110 Paula Findlen, "The Pope and the Englishwoman: Benedict XIV, Jane Squire, the Bologna Academy, and the Problem of Longitude", Benedict XIV and the Enlightenment:: Art, Science, and Spirituality, Messbarger, Rebecca, Johns, Christopher M. S., Gavitt, Philip, University of Toronto Press, 2016, 40-73, p. 47-48.
} 
Uppsala lacked the presence of a powerful and enlightened benefactor, such as Friedrich II in Prussia, or Benedict XIV in Italy, for astronomy to develop fully. Anders Celsius, an astronomer with a well-established international reputation, following his tour of Europe and his participation in the Maupertuis expedition to Lapland, nevertheless obtained in the early 1740s from the Senate of his University the construction and equipment of an observatory, albeit modest, but operational and equipped with some good instruments. The death of Celsius in 1744 interrupted the process of equipping the Observatory, which had been started by the Swedish manufacturer Ekström, probably because Hiorter was not a renowned observer and could not, or did not wish to, continue the equipment policy of his predecessor. He thus broke the momentum of the Uppsala Observatory's rise to prominence. As we have seen, it was only in 1751, one year after Hiorter's death, that Wargentin succeeded in attracting the royal power. This was largely thanks to the observation campaign coordinated with that of De la Caille at the Cape of Good Hope, for which he obtained royal funding for a team of Swedish observers spread over the territory, and at the same time the recognition of astronomy at the highest level of the State. However, Wargentin was unable to establish himself in Uppsala, so he set up an Observatory in Stockholm, operational in 1753, as part of the city's new Academy of Sciences.

\subsection{Conflicts of power}

In Uppsala, the untimely death of Celsius, founder of the Observatory, had unfortunate consequences since his successor Olof Hiorter quickly "privatised" the Observatory for his sole use, preventing Celsius' other pupil, Pehr Wilhelm Wargentin, from observing there, and observing little himself, as he was busy in other functions. This major dysfunction reflects the lack of effective control of the Observatory's operation by the university. This astonishing situation, which Delisle proposes to remedy by alerting the academic hierarchies of Uppsala and Stockholm, does not seem to have been resolved during Hiorter's five-years as director of the Observatory.

Delisle enjoyed extremely favourable living and salary conditions in St-Petersburg. First professor in astronomy at the Imperial Academy, he was, after the ambassador and the consul, the most important Frenchman in St-Petersburg ${ }^{111}$. Delisle's annual salary, 1800 rubles at the

\footnotetext{
${ }^{111}$ Chabin, op. cit. (ref. 82), p. 80.
} 
beginning of his stay, later increased to 2400 rubles, was very high. In fact it was double that of Chancellor Schumacher, secretary of the Academy and head of its administration, which was initially 800 rubles, later increased to 1200 rubles $^{112}$. Schumacher's salary was itself about twice the average salary of academicians, 400 rubles a year. Schumacher's powers, especially in terms of distributing the Academy's funds, were very important. The Library and the Museum of Natural History were placed under his responsibility from the very beginning of the Academy, in accordance with the wish of Peter the Great as stated in his draft statute of the Academy: "The library and the natural history cabinet of the Academy must be opened, so that the academicians do not lack the instruments necessary for their work. In order to run this sector, a special librarian is needed and the books and instruments needed by the Academy must be acquired; they must be ordered abroad or made at home". This point is essential because "it has often been said that in the years immediately following 1724, it was not the library and museum that were attached to the Academy, but the Academy of Sciences which began its activity on the fringes of the library and museum" ${ }^{113}$. Schumacher was in fact at the centre of the academic system, although he was not himself a scientist.

The delay in financing the instruments to be made by Vignon, which Delisle attributes in his letter to Maurepas to printing expenses, which monopolised the Academy's resources, could only generate impatience and resentment against Schumacher who, for his part, was envious of Delisle's high salary and thus deaf to his scientific demands. Delisle was an important and recognised scholar in the French and international astronomical community, reputed to have been endowed with a "dynamic and sometimes aggressive egocentricity"114. Delisle's ambitions at the Académie Impériale gradually asserted themselves, placing him in a position of direct confrontation with Schumacher. In his letter to the Senate of 12 September $1745^{115}$, he wrote that, in accordance with the regulations of 22 January 1724, reflecting the intentions

${ }^{112}$ Simon Werrett, "The Schumacher Affair: Reconfiguring Academic Expertise across Dynasties in Eighteenth-Century Russia”, Osiris, 25, 1, Expertise and the Early Modern State (2010), 104-126, p. 115.

${ }^{113}$ Shafranovskij, op. cit. (ref. 39), p. 605.

${ }^{114}$ Roger Jacquel, “L'astronome français Joseph-Nicolas Delisle (1688-1768) et Christfried Kirch (1694-1740) directeur de l'Observatoire de Berlin $(1716,1740)$ ”, Actes du $97^{\text {ème }}$ congrès national des sociétés savantes, Nantes, 1972, Section des sciences, Tome 1 (Paris, Bibliothèque Nationale, 1976), p. 414.

${ }^{115}$ Delisle, op. cit. (ref. 51). 
of Peter the Great, a professor should be appointed "President or perpetual director", and suggested that he himself, by virtue of his seniority and his knowledge of the institution, could be the first Director of the Academy thus appointed. The protracted power struggle between Delisle and Schumacher ${ }^{116}$ had obviously generated recurrent problems of funding for the day-to-day running of the Observatory, and the negative opinion on his working conditions expressed by Delisle in some of his letters is the result. As we have seen, the stock of instruments at Delisle's disposal at the Observatory seems to have been of a good standard, at least from 1735 onwards. It can probably be said that "after the Observatories in Paris and Greenwich, the Observatory in St-Petersburg was probably the best equipped in Europe"117, even though financial support for the equipment of the Observatory came only belatedly and Delisle's cartographic occupations were insufficiently supported in terms of personnel, thus reducing the time he could devote to astronomy. However, two astronomers were assigned to the Observatory to support it, enabling it to carry out a very substantial astronomical observation programme $e^{118}$.

\section{Conclusion}

First of all, it should be remembered that in the $17^{\text {th }}$ and $18^{\text {th }}$ centuries the state observatories were primarily oriented towards the application of astronomy to navigation and cartography, for both economic and military purposes, with the practice of science for its own sake remaining secondary. The Royal Observatory of Greenwich was founded by King Charles II for the specific and practical purpose of "rectifying the Tables of the Motions of the Heavens, and the places of the fixed Stars, so as to find out the so much desired Longitude of Places for perfecting the art of Navigation" "19. The Paris Observatory was created by Colbert to put the methods of astronomy at the service of the cartography of France and the improvement of world geography ${ }^{120}$. In Bologna, the program of the Academy of Sciences, approved by Luigi

\footnotetext{
${ }^{116}$ Werrett, op. cit. (ref. 112).

${ }^{117}$ Sigrist, op. cit. (ref. 1), p. 98.

${ }^{118}$ Struve, op. cit. (ref. 40), p. 91.
}

119 The Royal Observatory Greenwich,

http://www.royalobservatorygreenwich.org/articles.php?article=1053.

120 L'organisation de la science par Colbert, Histoire de l'Observatoire de Paris, https://sites.google.com/site/histoireobsparis/table-des-matieres/chapitre-1/lorganisation-de-la-sciencepar-colbert 
Ferdinando Marsigli, demanded that astronomical observations be "essential to Geography and Navigation... in open war and under military hardships", i.e., for carrying out reconnaissance of the territory that might be useful for military purposes: a direct and clearcut relation this between science and power and one that underlay the protection (and financing) that the kings of France and England lavished on the Observatories of Paris and Greenwich $^{121}$. As we have seen, it was with the main aim of mapping Russia that Peter the Great invited Joseph-Nicolas Delisle to work in St-Petersburg. Likewise, Celsius in Uppsala and Leibniz in Berlin both placed cartography and navigation at the forefront of the objectives of the academies whose creation they advocated.

The main conclusion of our study, which must be replaced in this context, is the extremely disparate nature of the conditions in which astronomy was practised in the four observatories belonging to the Academies in Berlin, Uppsala, Bologna and St-Petersburg. As we have seen, there were many reasons for these disparities, the first of which was of course the level of resources in terms of salaries and equipment, which depended not only on the level of recurrent funding, but also on sponsorships which provided once-off aid, often considerable, as in Berlin or Bologna. The service tasks assigned to astronomers - whether it was the production of calendars, which determined the level of resources of the Berlin Academy, or cartography, which generated essential resources for the astronomers in St-Petersburg, Paris and Greenwich - also constituted an obstacle to the exercise of their science. Conflicts of power in these young institutions, still devoid of regulatory bodies, sometimes took on a considerable dimension and paralysed activity, as in Uppsala, and on a larger scale in StPetersburg. Overall, the situation of astronomers in the mid-18th century in Berlin and Bologna, half a century after the creation of these academies, was still precarious, the initial development of these institutions having been slowed by the absence of a strong royal will to promote science. In St-Petersburg, it was the violent conflict between scientists and the administration that paralysed the system. In Sweden, astronomy only began to take on a real existence in the eyes of the royal power in the middle of the century with the creation of the Stockholm Observatory, which replaced the Historical Observatory at the University of Uppsala.

\footnotetext{
121 L'astronomia a Bologna, The impact of Galilean culture - From Bonaventura Cavalieri to Gian Domenico Cassini, https://museospecola.difa.unibo.it/english/sto1_10.html
} 
Acknowledgements: We are indebted to two anonymous Referees for their constructive suggestions, and to Rhoda Allanic for her help in improving the English of this article. 